\title{
The Influence of Cross-Generational Perception to the Leadership Style and Organizational Communication Atmosphere among Permanent Lecturers of STMIK Royal Kisaran
}

\author{
Rizky Fauziah, Prof. Lusiana Andriani Lubis, Dr. Dewi Kurniawati
}

Universitas Sumatera Utara

\begin{abstract}
The purpose of the research is to understand the effect of cross-generational perception to the leadership style and organizational communication atmosphere among permanent lecturers of STMIK Royal Kisaran. Quantitative correlation methods are utilize to see the correlation of cross-generational perception to affect the point of view of the leadership and organizational communication atmosphere. The research itself needs 2 months by using questionnaires and interviews to collect the clearest response from 62 respondents. The most important findings which found by the research is the difference perception of cross-generation between generation $X$ and generation $Y$ have an effect to the understanding of leadership style and organizational communication atmosphere. The cross-generation perception which is not in the same line has affect the term of ideal concept of leadership style and produce the uncomfort atmosphere of organizational communication. The factor which is affecting is the difference way of lifestyle, technology, and the less of tolerance in the cross-generation. The solution which can be propose is the alteration way of communication from the closed to be more open and democrative, to increase the tolerance from the situation, the mentoring from generation $X$ to generation $Y$ about the work experience and the mentoring from generation $Y$ to generation $X$ to understand the touch of technology.
\end{abstract}

Keywords: perception, leadership style, organizational communication atmosphere, STMIK Royal Kisaran

\section{Pre-Liminary}

\subsection{Background Case}

Generation $\mathrm{X}$ and $\mathrm{Y}$ define by the generational differences. Generational differences in simple is the mapping or grouping of human based on the number of ages which have a specific characterictics. The generational gap defines as the whole people in group from generation to the next generation categorized by the time and unique characteristics features. Each generation has their own perspective, common beliefs, and different behavior in politics, economics, and socials.

The difference of cross-generational nowadays becomes a huge issue to the labor force. Both of the Generations, which Generation X (born in 1965 - 1980) and Generation $\mathrm{Y}$ (born in 1981-1999) are having a different perspective so it cause a lot of miscommunication in daily organizational activity.

The perception between generations will affect the understanding of leadership style, because both are having their own frame of reference and field of experience and horizontal communication. This cause will affect to the effectiveness of communication atmosphere which be measured by IIK from Pace and Pearson. The communication atmosphere becomes the point to be focused on because this issue will affect the organization and productivity.

\subsection{Problem Statement}

These problem statements which are about to be researched, are: a) How far the correlation between perception and leadership style to the cross-generational among the permanent lecturers of STMIK Royal Kisaran?

b) How far the correlation between perception and organizational communication atmosphere among the permanent lecturers of STMIK Royal Kisaran?

c) How much the affect of cros-generational to the leadership style and organizational communication atmosphere among the permanent lecturers of STMIK Royal Kisaran?

\subsection{Research Purposes}

In simple, the research purposes are:

a) To analyze the correlation between the perception of cross-generational and leadership style of the crossgenerational permanent lecturers of STMIK Royal Kisaran

b) To analyze the correlation between the perception of cross-generational and the organizational communication atmosphere among the crossgenerational permanent lecturers of STMIK Royal Kisaran

c) To analyze the effect of cross-generational to the leadership style and organizational communication atmosphere among the cross-generational permanent lecturers of STMIK Royal Kisaran.

\subsection{Research Utility}

This research has several utility, which are: 


\section{International Journal of Science and Research (IJSR) \\ ISSN (Online): 2319-7064}

Index Copernicus Value (2016): 79.57 | Impact Factor (2015): 6.391

a)

Teoritical Aspects Utility

The results will contribute to the study of the crossgenerational, in specific in the field of perception, leadership style, and organizational communication atmosphere. This research added the reference which can be develop to the next research, especially in the interpersonal and organizational communication research.

b) Academics Aspects Utility

The results will contribute to the educational field, which can be used by the student who whilling to do the next research about the understanding of cross-generational perception and the effect to the organizational communication.

\section{c) Practically Aspects Utility}

Practically, the results will be used by the lecturers, campus managers, and the contributors of university. The research will help the parties who concerned about the understanding of perception of the cross-generational and the effect to the organizational communication.

\section{Literature Study}

\subsection{Background}

This research is exploiting by post-positivisme paradigm. In epistemologists, Salim (2001) describe that the correlation between the observer and the object which observed are cannot be separated. Post-positivisme believes that the subject will not reach the truth if the observers standing behind the screen with no direct touch with the object. Salim (2001:20), predicted and steady controlled are the purpose of post-positivisme. Postpositivisme think that human is impossible to reach the truth of the fact if the researcher makes a gap with the reality or in other word, the less of ability to involved to the reality. The connection from the researcher and the reality has to be interactive, so it needs the triangulation principle which is using several methods, source, and so on.

Table 2.1: Previous Research Literatures Title

The Next 20 Years: How Customers and Workforce Attitudes Will Evolve.

Author: Howe and Strauss

Pengaruh Work Place Fun terhadap Kinerja Karyawanberdasarkan Generational Differences (Studipada PT BXY).

Author: Yanti

Kepuasan Kerja Generasi X dan Generasi Y terhadap Komitmen Kerja di Bank Mandiri Palembang.

Author: Oktariani, Hubeis, and Sukandar

Komunikasi, Gaya Kepemimpinan, dan Motivasidalam Organisasi.

Author: DedeMahmudah

Peran Kepemimpinan Otentikterhadap Work Engagement Dosendengan Etifikasi Dirisebagai Mediator

Author: Hayuningtyas and Helmi Literatures Core

The difference between both generation ( $\mathrm{X}$ and $\mathrm{Y}$ ) will changes as the times due to the technology effect which is forming different culture pattern in each generation.

Different characteristics in each generations affecting the work process when both generation $(\mathrm{X}$ and $\mathrm{Y}$ ) working in the same workplace.

Giving the detail information about the differentiation between generation $\mathrm{X}$ and $\mathrm{Y}$ in working, which the generation $\mathrm{X}$ give their priority to loyalty and consistency while generation $\mathrm{Y}$ give their priority to teamwork and technological innovation.

Organization define by the style of leadership, because it's affect the effectivity of working communication and working motivation.

The contribution of lecturers and their loyalty in working determine the quality of productivity in teaching and to fulfill Tri Dharma University as their main function as a lecturer

\subsection{Theoretical Framework \\ 1.7.1 Perception and Culture Perception}

Perception and culture perception are part of interpersonal communication. Devito (2011: 80) said perception is a process which we will realize there is tons of stimuli affecting our senses. Perception affecting stimulus or message we absorb and the meaning that given to them when they reaching the awareness. Due to that explanation, perception is take an important role to the communication study in form and utility. Here we can see which (1) perception process, identify 3 main steps; (2) process which affecting perception; and (3) attribution, which is processing by the interpretation of our behavior and others.

\subsubsection{Organizational Communication}

Horizontal communication is the form of communication horizontally where messages exchange sideways and do by both parties at the same level, position, and same echelon in one organization. This communication utilize to informing, supporting and coordinating activity. Horizontal communication is utilized to saving time and easier to coordinating so it makes a short and fast action (Robbins, 2003). The convenience to Liaw (2005) due to the level, knowledge background and experience which almost the same between parties who communicate, and there is not so tight formal structural. 


\section{International Journal of Science and Research (IJSR) \\ ISSN (Online): 2319-7064}

Index Copernicus Value (2016): 79.57 | Impact Factor (2015): 6.391

\subsubsection{Leadership Style (Team Style)}

The leadership created by the work style or the way to work in team consistently. Based on what it's said (language) and what it's done (action), a person helping others to reach the desired results. The way a person to talk to others and the way a person to behave in front of others are the work style. The style concept shows that it is related to the combination of languages that describe a consistent pattern.

\subsubsection{Communicationn Atmosphere}

Pearson and Pace (1976) developed the Communicational Atmosphere Inventaris (IIK) which has been created to measured six "communication effects" based on the model from "ideal atmosphere related to management" equipped by Redding (1972). IIK utilized by Graff (1976), Bednar (1977), Baugh (1978), and Appalbaum and Anatol (1979) in the research of the atmosphere. The reability testing of IIK showed the coefficients from 0,8 to 0,97 , which was satisfied in general. The analytical factors IIK reported that IIK "can be utilized as the legitimate index for the organizational atmosphere among all".

\subsubsection{Generation $X$ and $Y$}

Characteristic and Behaviour of Generation $\mathrm{X}$ and $\mathrm{Y}$ in working.

\begin{tabular}{|l|l|l|}
\hline Generation & Gen-Xers & $\begin{array}{l}\text { Gen-Y } \\
\text { (Millenials) }\end{array}$ \\
\hline Behaviour & Scepticals & Realistic \\
\hline Character & $\begin{array}{l}\text { Categorized as the } \\
\text { most } \\
\text { "misunderstood" } \\
\text { generation or the } \\
\text { most } \\
\text { misunderstanding, } \\
\text { very independent, } \\
\text { lot of source }\end{array}$ & $\begin{array}{l}\text { Appreciate the } \\
\text { differentiation, } \\
\text { loves to } \\
\text { collaborate, } \\
\text { pragmatics in } \\
\text { making } \\
\text { decision. }\end{array}$ \\
\hline Working behaviour & $\begin{array}{l}\text { Desiring the } \\
\text { differentiation and } \\
\text { living in balance } \\
\text { between work life } \\
\text { and personal life, } \\
\text { making the job as } \\
\text { pressure, into the } \\
\text { high technology, } \\
\text { pragmatics }\end{array}$ & $\begin{array}{l}\text { Optimistic, } \\
\text { very focuses } \\
\text { on } \\
\text { achievement, } \\
\text { have a good } \\
\text { work ethic and } \\
\text { loves to serve } \\
\text { the } \\
\text { community, } \\
\text { loves to the } \\
\text { differentiation }\end{array}$ \\
\hline Desired Appreciation & free & $\begin{array}{l}\text { Into } \\
\text { challenging } \\
\text { job and } \\
\text { meaningful and }\end{array}$ \\
\hline Desired Career & moving & Parallel \\
\hline Yanti.
\end{tabular}

(Yanti. 2013. Universitas Indonesia)

\subsubsection{Generation $X$ and Characteristics}

Generation $\mathrm{X}$ is having a high commitment and loyality to the company where they having job. The generation $\mathrm{X}$ is having the caring nature as the responsibility to the personal job and feedback to the company, this condition makes this generation tend to stand out and having an important level in the company. Working is the main job and not so bored for generation $\mathrm{X}$ so they need the painstaking and patient to face all the work activity. Generation X even more tends to choose the job that sacrifices their personal needs. It makes generation $\mathrm{X}$ become a good example for generation $\mathrm{Y}$ in working at the same company.

\subsubsection{Generation $Y$ and Characteristics}

Generation $\mathrm{Y}$ is tend to have a less commitment and loyality in working, due to their less serious and trivial behavior. Back to the generation $\mathrm{Y}$, tend to feel their intelligence will so useful to the company. Because of that, reward, salary, and flexible time will be the main consideration for working under a company.

\section{$1.8 \quad$ Objectives}

Concept framework which proposed by the researcher based on the previous literatures study and research study were have been utilized to analyze both generation $\mathrm{X}$ and Y from the permanent lecturers of STMIK Royal Kisaran. This analytical utilize the theory interpersonal communication and communication organization to analyze the style of leadership and organization atmosphere.

\subsection{Theoretical Model}

Theoretical model which proposed by the researcher as the result of the concept framework that already mention before will directing to the making of research hypothesis.

\section{Research Methodology}

\subsection{Research Methods}

The research utilizes quantitative methods. Quantitative methods is a scientific research which systemized by parts and phenomenon's and also the connections. The measured process is the central part of quantitative research because it is delivering a fundamental connection between empirical observation and mathematical expression of quantitative connections.

\subsection{Population and Sampling Methods}

Population is the entire subject of the study (Arikunto S, 2002: 108). The population of the research is all the number of permanent lecturers in STMIK Royal Kisaran. The number of permanent lecturer's generation $\mathrm{X}$ in STMIK Royal is 25 persons meanwhile the permanent lecturers generation Y in STMIK Royal Kisaran is 37 persons.

\subsection{Collecting Data Methods}

The research utilizes single quantitative data methods (questionnaire). Questionnaire utilized as the main step in collecting data representing each opinion of crossgeneration which is generation $\mathrm{X}$ and generation $\mathrm{Y}$.

\section{Volume 6 Issue 12, December 2017}




\section{International Journal of Science and Research (IJSR) \\ ISSN (Online): 2319-7064}

Index Copernicus Value (2016): 79.57 | Impact Factor (2015): 6.391

Questionnaire will be share to the entire respondent to get their perception about the understanding of leadership style. Questionnaire will also utilize to measuring the IIK to the organizational communication atmosphere.

\subsection{Validity and Reliability}

Validity is a measurement showing the validation level or the legalization an instrument. An instrument can be called as valid if it can be measured the will and can reveal data of the variables studied appropriately (Notoatmojo, 2005). Reliability is a data collection tool or instrument which quite reliable to be used as a data collection tool because the instrument is decent (Arikunto 2006). Assessment of reliability in this study was conducted with internal consistency which is to test the instrument just once only.

\subsection{Data Analysis Methods}

After the data collected from the results of data collection, then in outline according Sugiyono (2002: 74) data management steps, namely:

a)Editing, i.e. rechecking the questionnaire that was collected after filled by the respondent. The inspection concerns the completeness of filling the questionnaire thoroughly.

b) Coding, which is the coding or scoring for each choice of each item of the existing provisions.

c) Tabulating, in this case the results of coding poured into a complete recapitulation table for all items on each variable.

d) The data obtained then processed, after that obtained the details of the score and position of respondents based on the inquiry sequence incoming for each variable $\mathrm{X}$ and Y.

e) Data analysis, i.e. describe variable $\mathrm{X}$ and variable $\mathrm{Y}$.

\subsection{Data Analysis Techniques}

The data analysis technique utilized in this research is Rank Spearman Correlation. The use of this correlation aims to find the relationship or the significance of the hypothesis when each variable which is connected ordinal shaped, and data sources between variables should not be the same.

\section{Research Findings}

\subsection{General Description STMIK Royal Kisaran}

Educational Foundation Royal Teladan Asahan as a Private University Organizing Board (BPPTS) in Asahan Regency background of the establishment of STMIK Royal Kisaran. The rapid development of information technology requires the existence of universities in the region that contribute to improve the human resources (HR) Indonesia which competent, independent, innovative, adaptive and able to compete in regional, national and international levels and take efforts to adjust the development of globalization era. Royal College of Information and Computer Management (STMIK) Royal Kisaran is on Jalan Prof. H. M. No. 173 Kisaran, Kisaran
Naga Sub-District East Kisaran, Asahan Regency, North Sumatra Province.

\subsection{Research Results}

\subsubsection{Variable Validity test}

\begin{tabular}{|c|c|c|c|c|}
\hline No. & Item & R Table & $\begin{array}{c}\mathbf{R} \\
\text { Calculate }\end{array}$ & Explanation \\
\hline 1 & P5 & 0,256 & 0,441 & Valid \\
\hline 2 & P6 & 0,256 & 0,417 & Valid \\
\hline 3 & P7 & 0,256 & 0,673 & Valid \\
\hline 4 & P8 & 0,256 & 0,418 & Valid \\
\hline 5 & P9 & 0,256 & 0,329 & Valid \\
\hline 6 & P10 & 0,256 & 0,778 & Valid \\
\hline 7 & P11 & 0,256 & 0,471 & Valid \\
\hline 8 & P12 & 0,256 & 0,618 & Valid \\
\hline 9 & P13 & 0,256 & 0,545 & Valid \\
\hline 10 & P14 & 0,256 & 0,788 & Valid \\
\hline 11 & P15 & 0,256 & 0,718 & Valid \\
\hline 12 & P16 & 0,256 & 0,635 & Valid \\
\hline 12 & P17 & 0,256 & 0,784 & Valid \\
\hline 14 & P18 & 0,256 & 0,817 & Valid \\
\hline 15 & P19 & 0,256 & 0,645 & Valid \\
\hline 16 & P20 & 0,256 & 0,703 & Valid \\
\hline 17 & P21 & 0,256 & 0,867 & Valid \\
\hline 18 & P22 & 0,256 & 0,540 & Valid \\
\hline 19 & P23 & 0,256 & 0,257 & Valid \\
\hline 20 & P24 & 0,256 & 0,269 & Valid \\
\hline 21 & P25 & 0,256 & 0,450 & Valid \\
\hline 22 & P26 & 0,256 & 0,310 & Valid \\
\hline 23 & P27 & 0,256 & 0,274 & Valid \\
\hline & & & & \\
\hline
\end{tabular}

\subsubsection{Variable Reability Test}

Reability Test Result

\begin{tabular}{|c|c|}
\hline $\begin{array}{c}\text { Cronbach's } \\
\text { Alpha(a) }\end{array}$ & N of Items \\
\hline .724 & 23 \\
\hline
\end{tabular}

\subsubsection{Respondent's Answers Distribution to Respondent's Characteristics}

Based on the questionnaires that have been distributed to the respondents of the permanent lecturers STMIK Royal Kisaran, this following explanation from each description of the data characteristics of respondents who become components in the questionnaire.

Gender

\begin{tabular}{|c|c|c|}
\hline Gender & Frequency & $\begin{array}{c}\text { Percentage } \\
(\boldsymbol{\%})\end{array}$ \\
\hline Woman & 17 & 27,4 \\
\hline Man & 45 & 72,6 \\
\hline Total & 62 & 100,0 \\
\hline
\end{tabular}

Year of Birth

\begin{tabular}{|c|c|c|}
\hline Year of Birth & Frequency & Percentage (\%) \\
\hline $\begin{array}{c}1965-1980 \\
\text { (Generation X) }\end{array}$ & 25 & 45,2 \\
\hline $\begin{array}{c}1981-1990 \\
\text { (Generation Y) }\end{array}$ & 37 & 54,8 \\
\hline Total & 62 & 100,0 \\
\hline
\end{tabular}

\section{Volume 6 Issue 12, December 2017}


Index Copernicus Value (2016): 79.57 | Impact Factor (2015): 6.391

Education Background

\begin{tabular}{|c|c|c|}
\hline Education & Frequency & Percentage (\%) \\
\hline Computer Science & 45 & 72,6 \\
\hline Economics & 3 & 4,8 \\
\hline Natural Science/Exact & 9 & 14,5 \\
\hline Social Science & 4 & 6,5 \\
\hline Others & 1 & 1,6 \\
\hline Total & 62 & 100,0 \\
\hline
\end{tabular}

Ethnic

\begin{tabular}{|c|c|c|}
\hline Ethnic & Frequency & Percentage \\
\hline Bataknese & 13 & 21,0 \\
\hline Javanese & 6 & 9,7 \\
\hline Sundanese & 3 & 4,8 \\
\hline Malayanese & 3 & 4,8 \\
\hline Minangnese & 37 & 59,7 \\
\hline Total & 62 & 100,0 \\
\hline
\end{tabular}

4.2.1.2 Respondent's Answers Distribution to The Permanent Lecturers of STMIK Royal Kisaran Perception

\section{A. Dimensional Stimulus}

Talks About Characteristics Between Generations Among Permanent Lecturers

\begin{tabular}{|c|c|c|}
\hline Response & Frequency & $\begin{array}{c}\text { Percentage } \\
(\mathbf{\%})\end{array}$ \\
\hline Very Often & 0 & 0,0 \\
\hline Often & 0 & 0,0 \\
\hline Less Often & 34 & 54,8 \\
\hline Never & 28 & 45,2 \\
\hline Total & 62 & 100,0 \\
\hline
\end{tabular}

The Knowledge about Generation X and Y

\begin{tabular}{|c|c|c|}
\hline Response & Frequency & $\begin{array}{c}\text { Percentage } \\
(\mathbf{\%})\end{array}$ \\
\hline $\begin{array}{c}\text { Very } \\
\text { Understand }\end{array}$ & 4 & 6,5 \\
\hline Understand & 34 & 1,6 \\
\hline $\begin{array}{c}\text { Less } \\
\text { Understand }\end{array}$ & 23 & 37,1 \\
\hline $\begin{array}{c}\text { Do Not } \\
\text { Understand }\end{array}$ & 1 & 1,6 \\
\hline Total & 62 & 100,0 \\
\hline
\end{tabular}

B. Organizational Dimension

Teamwork between Not from Your Generation Lecturers

\begin{tabular}{|c|c|c|}
\hline Response & Frequency & $\begin{array}{c}\text { Percentage } \\
(\mathbf{\%})\end{array}$ \\
\hline Very Often & 0 & 0,0 \\
\hline Often & 4 & 6,5 \\
\hline Less Often & 43 & 69,4 \\
\hline Never & 15 & 24,1 \\
\hline Total & 62 & 100,0 \\
\hline
\end{tabular}

Getting Conflict When Working With Not From Your Generation Lecturers

\begin{tabular}{|c|c|c|}
\hline Response & Frequency & $\begin{array}{c}\text { Percentage } \\
(\mathbf{\%})\end{array}$ \\
\hline Very Often & 3 & 4,8 \\
\hline Often & 30 & 48,4 \\
\hline Less Often & 29 & 46,8 \\
\hline Never & 0 & 0,0 \\
\hline Total & 62 & 100,0 \\
\hline
\end{tabular}

4.2.1.3Respondent's Answers Distribution to The Permanent Lecturers Perception to The Leadership Style in STMIK Royal Kisaran

The Leadership Style of the Chairman of STMIK Riyal Kisaran to Appreciate the Agreement of the Lecturers as the Results of Deliberation

\begin{tabular}{|c|c|c|}
\hline Response & Frequency & $\begin{array}{c}\text { Percentage } \\
(\mathbf{\%})\end{array}$ \\
\hline Very Agree & 1 & 1,6 \\
\hline Agree & 24 & 38,8 \\
\hline Disagree & 34 & 54,8 \\
\hline $\begin{array}{c}\text { Very } \\
\text { Disagree }\end{array}$ & 3 & 4,8 \\
\hline Total & 62 & 100,0 \\
\hline
\end{tabular}

The Leadership Style of the Chairman of STMIK Riyal Kisaran Strong Idealism for Positive Contribution in Campus Development

\begin{tabular}{|c|c|c|}
\hline Response & Frequency & $\begin{array}{c}\text { Percentage } \\
(\mathbf{\%})\end{array}$ \\
\hline Very Agree & 1 & 1,6 \\
\hline Agree & 21 & 33,9 \\
\hline Disagree & 36 & 58,1 \\
\hline $\begin{array}{c}\text { Very } \\
\text { Disagree }\end{array}$ & 4 & 6,4 \\
\hline Total & 62 & 100,0 \\
\hline
\end{tabular}

The Leadership Style of the Chairman of STMIK Riyal Kisaran Finding Reasons for the Differences in Conflict

\begin{tabular}{|c|c|c|}
\hline Response & Frequency & $\begin{array}{c}\text { Percentage } \\
(\boldsymbol{\%})\end{array}$ \\
\hline Agree & 36 & 58,1 \\
\hline Disagree & 25 & 40,3 \\
\hline $\begin{array}{c}\text { Very } \\
\text { Disagree }\end{array}$ & 1 & 1,6 \\
\hline Total & 62 & 100,0 \\
\hline
\end{tabular}

4.2.1.4. Respondent's Answers Distribution to the Permanent Lecturers Perception to the Organization Communication Atmosphere in STMIK Royal Kisaran

You Feel That the Organization Communication Atmosphere between Generations is Condusive.

\begin{tabular}{|c|c|c|}
\hline Response & Frequency & $\begin{array}{c}\text { Percentage } \\
(\boldsymbol{\%})\end{array}$ \\
\hline Very Agree & 0 & 0,0 \\
\hline Agree & 3 & 4,8 \\
\hline Disagree & 45 & 72,6 \\
\hline $\begin{array}{c}\text { Very } \\
\text { Disagree }\end{array}$ & 14 & 22,6 \\
\hline Total & 62 & 100,0 \\
\hline
\end{tabular}

Volume 6 Issue 12, December 2017 


\section{International Journal of Science and Research (IJSR) \\ ISSN (Online): 2319-7064}

Index Copernicus Value (2016): 79.57 | Impact Factor (2015): 6.391

You Feel There is The Effect of Each Generation Characteristics to The Condusivity of Campus Organization Atmosphere

\begin{tabular}{|c|c|c|}
\hline Response & Frequency & $\begin{array}{c}\text { Percentage } \\
(\mathbf{\%})\end{array}$ \\
\hline Very Agree & 5 & 8,1 \\
\hline Agree & 49 & 79,0 \\
\hline Disagree & 8 & 12,9 \\
\hline $\begin{array}{c}\text { Very } \\
\text { Disagree }\end{array}$ & 0 & 0,0 \\
\hline Total & 62 & 100,0 \\
\hline
\end{tabular}

You See There Is an Effect of Each Generation Characteristics to the Perspective of Leadership Style

\begin{tabular}{|c|c|c|}
\hline Response & Frequency & $\begin{array}{c}\text { Percentage } \\
(\mathbf{\%})\end{array}$ \\
\hline Very Agree & 4 & 6,5 \\
\hline Agree & 57 & 91,9 \\
\hline Disagree & 1 & 1,6 \\
\hline $\begin{array}{c}\text { Very } \\
\text { Disagree }\end{array}$ & 0 & 0,0 \\
\hline Total & 62 & 100,0 \\
\hline
\end{tabular}

4.3 The Average Differentiation Bivariate Analysis for Groups X and Group Y

Independent Samples Test

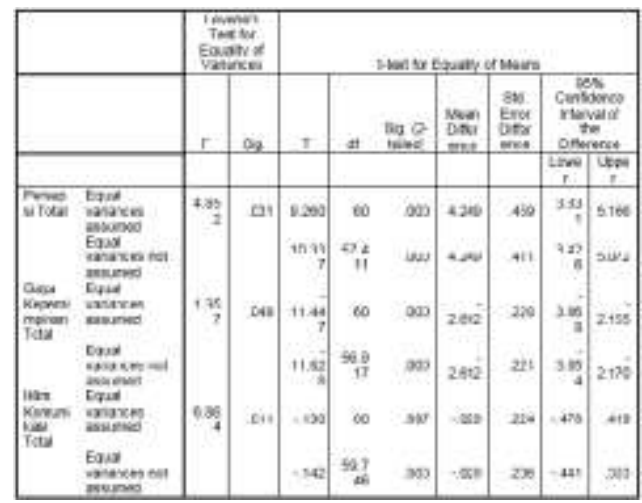

4.2.3.1 The Correlation of Cross-Generational Perception to The leadership Organization Style in STMIK Royal Kisaran

\section{Correlation}

Correlation Table (1)

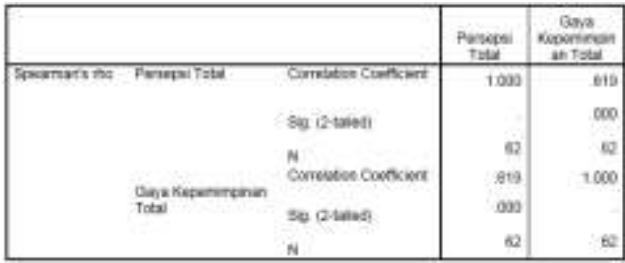

4.2.3.2 The Correlation of Cross-Generational Perception to The Organization Communication Atmosphere in STMIK Royal Kisaran

\section{Correlation}

Correlation Table (2)

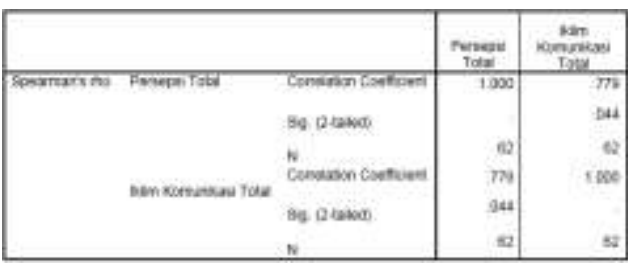

\subsection{Multivariate Analysis}

Multivariate Anova Test (1)

\section{Model Summary}

Multivariate Tests(b)

\begin{tabular}{|c|c|c|c|c|c|c|}
\hline Enst & & wens & $t^{f}$ & Hotsteris of & Etras al & 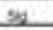 \\
\hline \multirow[t]{4}{*}{ लिखेक्र } & Pिकाता & 997 & 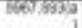 & 2000 & 56000 & .200 \\
\hline & What Lartids & am & veer ansa' & 2000 & sem & 209! \\
\hline & Haterenes Trase & 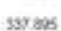 & 6ed mas & 2000 & 50000 & 200 \\
\hline & 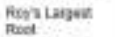 & $23 / 205$ & $\operatorname{tec} \sin \frac{1}{4}$ & 2000 & 50000 & 200 \\
\hline \multirow[t]{4}{*}{ Ast } & Perintines & 30 & Iอ กมะ(a) & 2000 & 50000 & 000 \\
\hline & Whe iameas & $65:$ & 75335 ai & 2000 & 60000 & ox: \\
\hline & Heteino tix: & sit & ts $355(a)$ & 2000 & 50000 & $m$ \\
\hline & Nogen Largose & $s a t$ & 15 nas:a) & $2 \mathrm{mon}$ & 50000 & ox \\
\hline
\end{tabular}

Multivariate Anova Test (2)

\section{Tests of Between-Subjects Effects}

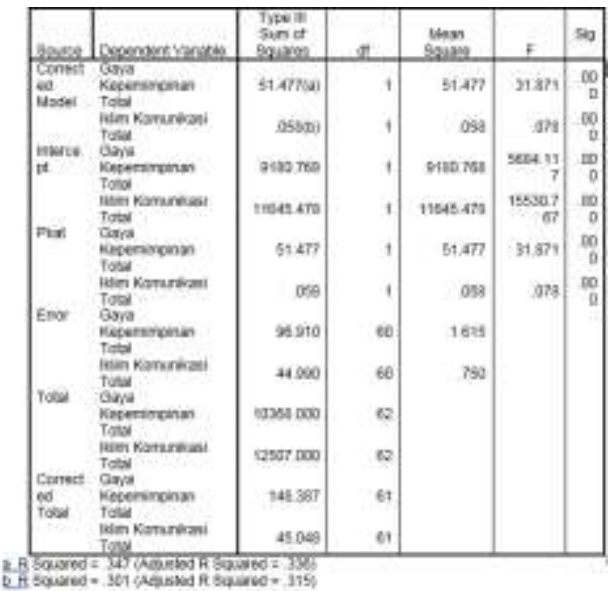

\section{Research Discussion}

From the results known that the most respondents came from male gender that is 45 people $(72.6 \%)$ while female respondents are as many as 17 people $(27.4 \%)$. From the research results also known that most respondents born between 1981 - 1990 (Generation Y) that is as many as 37 people $(54.8 \%)$. While respondents born between the years 1965 - 1980 (Generation X) as many as 25 people (45.2\%).

The results showed that most respondents have computer science education as much as 45 people $(72.6 \%)$. While the others are economics 3 people $(4.8 \%)$, natural sciences / exact as many as 9 people (14.5\%), social science as much as 4 people $(6.5 \%)$ and other disciplines 1 person $(1$, $6 \%$ ). This is understandable because STMIK Royal is a

Volume 6 Issue 12, December 2017

www.ijsr.net

Licensed Under Creative Commons Attribution CC BY 


\section{International Journal of Science and Research (IJSR) \\ ISSN (Online): 2319-7064}

Index Copernicus Value (2016): 79.57 | Impact Factor (2015): 6.391

computer science college so that majority of its lecturers have discipline in computer field, while from the research result also known that most respondents are Minangsnese that is 37 people $(59,7 \%)$. While others include 13 people $(21.0 \%)$, Javanese as many as 6 people $(9.7 \%)$, Sundanese as many as 3 people $(4.8 \%)$ and Malayanese as many as 3 people $(4.8 \%)$. The majority of lecturers at STMIK Royal come from West Sumatera because to take the master degree education in the field of computer science, the closest comes from West Sumatra, take the Minangnese become majority of lecturers at STMIK Royal.

\subsection{The Data Interpretation on The Cross- Generational Permanent Lecturers of STMIK Royal Kisaran}

Based on statistical analysis with independent sample t test known that there is a difference between generation $\mathrm{X}$ with generation $\mathrm{Y}$ in perception variable that is with $\mathrm{p}$ value $0,031<0,05$. While the leadership style variable is also known and proved significantly there is a difference between generation $\mathrm{X}$ and generation $\mathrm{Y}$ to see the leadership of the chairman of STMIK Royal Kisaran with $\mathrm{p}$ value $=0.049<0.05$. For communication atmosphere variables also proved significantly with $\mathrm{p}=0.011<0.05$ there is a difference between generation $\mathrm{X}$ and generation $\mathrm{Y}$ to see the communications atmosphere at STMIK Royal Kisaran.

\subsection{Correlation Perception of Permanent Lecturer with Leadership Style of The Chairman of STMIK Royal Kisaran.}

Based on statistical analysis with spearman correlation proved significantly with $\mathrm{p}=0.0001<0,05$ there is correlation between perception of permanent lecturer with leadership style of the chairman of STMIK Royal Kisaran. The value of correlation coefficient of 0.619 which means there is a close high connection and positive value between the perception of permanent lecturer with the leadership style of the chairman of STMIK Royal Kisaran where the better the perception of the better leadership style run by the chairman of STMIK Royal Kisaran.

\subsection{Correlation Perception of Permanent Lecturer with Communication Atmosphere of STMIK Royal Kisaran.}

Based on statistical analysis with spearman correlation proved significantly with value $p=0,044<0,05$ there is correlation between perception of permanent lecturers with communication atmosphere at STMIK Royal Kisaran. The value of correlation coefficient of 0.779 which means there is a close high connection and positive value between the perception of permanent lecturers with communication atmosphere at STMIK Royal Asahan where the better the perception of the better communication atmosphere in STMIK Royal Kisaran.
5.4 The Effect of Cross-Generation Perception with Leadership Style of the Chairman of STMIK Royal Kisaran and the Communication Atmosphere Among Lecturers

Based on the research results can be seen that the crossgenerational perception simultaneously affect significantly independent variables of leadership style and communications atmosphere because $4 \mathrm{p}$-value shows the number $<0,05$. The results tell us if there is a significant effect of the independent variable on all the dependent variables. If you are asked "Overall, is there a significant effect of the independent variables on a set of dependent variable groups", "then you will run MANOVA and see the results of this multivariate test as your conclusion". "Which means, if $4 \mathrm{p}$-value show $<0.05$, then it is significant at the $95 \%$ trust level".

\section{Conclusions and Suggestions}

\subsection{Conclusion}

Based on the results can be concluded:

1. There is the effect of cross-generational perception and leadership style among permanent lecturers of STMIK Royal Kisaran. Based on the results obtained, there is a difference between the perceptions of generation $\mathrm{X}$ and generation $Y$ due of differences in background, technology, and lack of tolerance because of the lack of awareness of the differences between generations.

2. There is the effect of cross-generational perception and organization communication atmosphere among permanent lecturers of STMIK Royal Kisaran. After seeing the difference of perception between generation $\mathrm{X}$ and $\mathrm{Y}$ generation besides not only affecting the meaning of leadership style but also effecting to organization communication atmosphere.

There is an effect of cross-generational perception between leadership style and organizational communication atmosphere among permanent lecturers of STMIK Royal Kisaran. Differences in perceptions between generations cause the distance between each generation and leadership style of the chairman of STMIK Royal who can not minimize this condition. The impact is the organizational communication atmosphere tends to be negative because it does not provide a space for each generation interdependent each other.

\subsection{Suggestions}

Suggestions can be given in two main points: lecturers and campus managers (The Chairman of STMIK Royal and their vices) For teaching staff or lecturers it is advisable to maintain a conducive working atmosphere on campus so as to maintain affective commitment to organizations (campus), for example by boldly expressing opinions, ideas and criticisms, raising awareness of the progress and development of the campus and also trying to follow all campus activities related to campus interests, trying to 


\section{International Journal of Science and Research (IJSR) \\ ISSN (Online): 2319-7064}

Index Copernicus Value (2016): 79.57 | Impact Factor (2015): 6.391

improve intellectual and spiritual skills in teaching for the benefit of the campus and be discipline.

For the manager of STMIK Royal Campus in this case headed by a Chairman with the ranks Vice Chairman 1, 2, and 3. The thing that must be considered for the development of the campus in the future is trying to maintain a positive perception of the lecturers such as taking the time together with the lecturers. Through this action, is expected to be established proximity between the Chairman STMIK Royal Kisaran and the lecturers. It is also more open to criticism and suggestions from the lecturers which can be an evaluation of the leadership applied by the Chairman of STMIK Royal Kisaran. Besides, can also be done by improving the communication quality between the chairman and the lecturers, for example by periodically conducting evaluation meetings in which lecturers are allowed to propose creative ideas about the progress and campus development. If indeed it turns out the teaching staff can not follow the rules and provisions imposed by the management of the campus managers can provide strict sanctions ranging from letters of reprimand up to a 3 times maximum and the most severe sanction of dismissal from the position as a lecturer.

\section{References}

[1] Ajeng, Kartika. \& Sopranita. (2014). Organization: Perusahaan Terhadap Kinerja Karyawan Dengan Motivasi Kerja Sebagai Variable Moderating. Skripsi: Universitas Muhammadiyah Surakarta.

[2] Al-Rasyid, Harun. 1994. Teknik Penarikan Sampeldan Penyusunan Skala. Bandung: Universitas Padjajaran.

[3] Arikunto, S. (2002). Prosedur Penelitian Suatu Pendekatan Praktik. Jakarta: PT Rineka Cipta.

ProsedurPenelitianSuatuPendekatanPraktik. Jakarta: PT RinekaCipta.

[5] Arni, Muhammad. (2005). KomunikasiOrganisasi . Jakarta: BumiAksara.

[6] Augusty, Ferdinand.

(2006)

MetodePenelitianManajemen:

PedomanPenelitianuntukSkripsi,TesisdanDisertaill muManajemen. Semarang: UniversitasDiponegoro.

[7] Blake and Mouton (1985). Leadership Style: a Matter of Balance, Internet: http:/www.Amilybusiness-expert.com/leadership-style.html

[8] Constantine, G. (2010). Tapping into Generation Y: Nine Ways Community Financial Institutions Can Use Technology to Capture Young Customers. Retrieved 8 November 2015, fromhttp://files.firstdata.com/downloads/thoughtleadership/geny_wp.pdf.

[9] Creswell, John. W. (2013). ResearchDesign: PendekatanKualitatif,

KuantitatifdanMixedEdisiKetiga. Yogyakarta: PustakaPelajar.

[10] Cummings and Worley. (2008). Organization Development \& Change. USA: CengangeLearning.

[11] Devito, Joseph. A. (2011). KomunikasiAntarManusia. Tanggerang Selatan: Karisma.

$[12]$

\section{Communication \\ PearsonEducation.}

[13] Emzir. (2009). The Interpersonal Book12 ${ }^{\text {th }}$ Edition. USA: MetodologiPenelitianPendidikanKuantitatif\&Kualit atif. Jakarta: Rajawali Press.

[14] Fajar, Marhaeni. IlmuKomunikasiPerspektif, Proses danKonteks. Bandung: WydiaPadjajaran.

[15] Fitriyani, Eni. Kresna Duta Agroindo Perkebunan Sinar Mas Group KecamatanKombengKabupatenKutaiTimur. Journal IlmuKomunikasi, 1(2), 518-531.

[16] Gamble dan Gamble. (2005). Communication Works $8^{\text {th }}$ Edition. New York: McGraw-Hill.

[17] Gerungan, W.A. (1996). PsikologiSosial. Ed ke-2. Bandung: PT. RefikaAditama.

[18] Ghozali, Imam. (2001). AplikasiAnalisis Multivariate Dengan Program SPSS. Semarang: BadanPenelitiUniversitasDiponegoro.

[19] Handoko, T. Hani. (2000). Organization: Perusahaan TeoriStruktur Dan Perilaku. Ed ke2. Yogyakarta: BPTE.

[20] HayunningtyasdanHelmi.

PeranKepemimpinanOtentikterhadapWork

EngangementDosendenganEtifikasiDirisebagai

Mediator. GadjahMadaJournal of Psyhology Vol. 1, No. 3.

[21] Hersey. (2004). KunciSuksesPemimpinSituasional. Jakarta: Delaprasata.

[22] Horovitz, B. (2012). After Gen X, Millenials, What Should Next Generation Be?. USA Today. Retrieved 4 November 2015, from. http://usatoday30.com/money/advertising/story/201 2-05-03/naming-yhe-next-generation/54737518/1

[23] Howe dan Strauss. (2007). The Next 20 years: How Customer and Workforce Attitudes Will Evolve. USA:Harvard Business Review.

[24] Intifada, R. danNurtjahjanti, H. (2013). HubunganantaraPerceived Organizational Support denganOrganizational Citizenship Behavior padaKaryawan Hotel Pendanaran Semarang. JurnalEmpati. Vol.2, No.3.

[25] Jalaludin, Rakhmat. (2007). PersepsiDalam Proses BelajarMengajar. Jakarta: Rajawali Pers.

[26] Jayanti, Tri. (2012). MengurangiPerilakuSiswaTidakTegasMelaluiPende katanRebtdenganTeknikAssertive Training. Indonesia Journal of Guidance and Counseling: Theory and Application Vol. 1, No. 1.

[27] Judge, T.A. dan Bono, J.E. (2000). Five-factors Model of Personality and transactional Leadership. Journal of Applied Psychologi, 85 (5): 751-765.

[28] Kartono, Kartini. (2009). PemimpindanKepemimpinan. Jakarta: Rajawali Pers.

[29] Letourneau, N. dan Allen, M. 1999. PostPositivisme Critical Multiplism: A Beginning 


\section{International Journal of Science and Research (IJSR)}

ISSN (Online): 2319-7064

Index Copernicus Value (2016): 79.57 | Impact Factor (2015): 6.391

Dialogue. Journal of Advanced Nursing Vol. 30, No. 03.

[30] Liaw, Ponijan . (2005 ). Understanding Your Communication Styles. Bandung:Sidoku Press.

[31] Liliweri, Alo. (2015). KomunikasiAntar Personal. Jakarta: PT. AdhityaAndrebinaAgung.

[32] Lubis, LusianaAndriani. (2014). PemahamanPraktisKomunikasiAntarBudaya. Medan: USU Press.

[33] Luthans, F. (2014). Organization Behavior. New York: McGraw Hill International.

[34] Mathis dan Jackson. (2002). ManajemenSumberDayaManusi. Jakarta: PT. SalembaEmpat 